\title{
Analysis of the Utilization of Museums as Historical Learning Media by High School Teachers
}

\author{
Rahmuliani Fithriah ${ }^{1 *}$, Najmi $^{1}$ \\ ${ }^{1}$ Fakultas Ilmu Sosial, Universitas Negeri Padang, Indonesia \\ ${ }^{*}$ Corresponding author. Email: rahmuliani@ fis.unp.ac.id
}

\begin{abstract}
This paper describes utilization of the Museum by high school teachers in Sawahlunto City. As we known that museums are a source of learning that can be used by teachers in the process of learning history, so the values of past events and the values of characters expected to be understood by students can reach students well. The city of Sawahlunto is a Colonial city which keeps many traces of past events that have now been kept in museums managed by the government. Some of them are Museum Gudang Ransum, Kereta Api and Lubang Mbah Suro. This article is the result of research on the understanding of the history teachers of Sawahlunto City High School to use of the Museum as one of the history learning media. Through observations and interviews conducted, the results were obtained that the history teachers at Sawahlunto City High School had not been maximized in utilizing the Museum as a medium of learning history. Although the Museum has done several activities that will attract visitors to come to the Museum. Through this research it is hoped that it can help history teachers understand the importance of using museums and start utilizing museums in learning history.
\end{abstract}

\section{Keywords: Museum, learning media, learning history}

\section{INTRODUCTION}

Education aims to make people smarter and also helps to make people better (morally), in other words education aims to change someone behavior for the better. Educating students to be smart may not be a difficult thing, but educating students to be good human beings (goodperson), and wise, it seems much more difficult if we look at the current development (Ajat Sudrajat;2011). Schools are required to be able to play their roles and responsibilities to instill and develop good values and help students shape and build their character. These values include the character of students who have respect, responsibility, honesty, caring, and fair. Good character is also needed to be a good citizen who has a love for his homeland. One of the lessons that is expected to foster good character and respect for the nation is the study of history, because to become a great nation, citizens must respect its history.

Current developments in technology demand that teaching and learning processes must also be able to adjust to these developments. Therefore, teachers are required to be able to use learning media so that the information and messages to be conveyed can be reached and understood by students. Likewise with the study of History where the object of study is all human activity that has occurred in the past, of course requires the media as a means to convey information in order to be able to present these historical events in class. One of the historical learning media that can be used is the Museum. However, in the learning process not all history teachers are aware and use the museum as one of the media in their teaching. This might

be caused by several things that need to be analyzed further.

The museum has a function as a non-formal educational institution which is a means of learning without having to involve the role of the teacher like learning in the classroom with the lecture system. In addition, student awareness of past events can also be increased through museums. Therefore, the museum contributes to education in schools in many ways, one of which is visual communication through prehistoric objects on historical subjects that become more alive, clear and effective through exhibitions in the museum (Singh Prabhas Kumar, tanpa tahun:74).

According to Tsabit Azinar, as quoted by Ummi Hartati in the Historia Journal, the use of museums as learning media is also possible because of the complexity of the available media as an explanation of an event. The media are in the form of models, realities, tables, posters or electronic multimedia systems such as audio visual. (Tsabit Azinar Ahmad, 2010:113). The museum should have a very important function for general learning and history learning in particular. This is because events as objects in learning history cannot be presented directly in the classroom to students because they have happened long ago. Therefore, to be able to get a picture of these historical events, the teacher can use a museum that stores evidence of an event from an event. history, because the museum is an excellent place or place to develop the imagination of students. This is in line with the progress of the current era, where students feel more interested in 
learning through learning media such as videos, documentaries, pictures, etc., than just reading a book and only listening to the teacher's explanation in front of the class.

One of the cities that have museums that store objects related to the history of the Indonesian people is the Museum located in Sawahlunto City. Some of them are Museum Kereta Api and Museum Gudang Ransum. As is well known that Sawahlunto City is a Colonial City that was formed due to the arrival of the Dutch people who wanted to exploit Coal as a natural resource owned by Sawahlunto City. As a city formed by the process of colonization, so many relics of the Dutch era can be found. This is what caused the city, which was once known as the Mining City, to become a Tourism City that offers historical tours and natural attractions of former coal mining.

Therefore, it is very appropriate if the Museum is a source of learning for students. But a question arises, have the high school history teachers in Sawahlunto City have used the museum as a medium in learning history? To what extent have teachers utilized the museum in the history learning process at the Sawahlunto City Middle School? Is the museum able to carry out its function as a learning facility in Sawahlunto City?

\section{METHOD}

The method used in this study is the historical method as stated Gilbert. J. Garragan covering the stages of heuristics, source criticism, interpretation and writing (hitoriografi).

At the Heuristic stage, written and oral data will be collected through interviews with high school history teachers in Sawahlunto City and parties from the museum. In addition to interviews, data will also be obtained through observation. Through these data it is hoped that an overview can be obtained about the use of museums by high school history subjects in Sawahlunto City. The second stage is Source Criticism. External criticism tries to find the authenticity of the source.

Data archives, for example, need more attention especially related to source profiles; paper, ink, dates, and other possible forms of falsification because they have gone through a process, doubling such as the existence of an empty gap that gives an indication of word deletion. In internal criticism primarily is an attempt to find the truth of the contents of the document by understanding the style of language used, the spelling used and terminology.

The truth of the source content will also be sought by comparing. In the third stage, namely interpretation, a series of historical facts that are glued together with historical interpretation is called a historical story. Each story is required to be objective. After the final stages of this study are interpreted, it is Historiography which means the stages of writing the results of the research.

\section{RESULTS AND DISCUSSION}

Based on observations and interviews with high school teachers in the city of Sawahlunto, information was obtained that in the history learning process in the classroom the teacher had not used the museum to its full potential. This is because the teachers prefer to use media images or videos obtained from the Internet. This is considered more practical and saves time. Another reason is because these teachers still do not understand the benefits of using museums as a medium in learning history. Therefore, giving understanding in the form of seminars is felt necessary to be given to the history teacher in the City of Sawahlunto in the future, so that the teacher knows that by bringing students to visit the museum will provide a better understanding and experience of learning history.

This is very unfortunate, because the Museum in the City of Sawahlunto has changed and improved its condition so that it is ready to receive visits from various parties, especially students who want to study mining history during the Dutch Colonial period in Sawahlunto City. Through interviews with museum administrators, the data obtained regarding the classification of visitors who have used the museum for the last 5 years, namely: 1) Students or Students from Kindergarten to Higher Education level both from domestic and from abroad. 2) Employees in State and Private Institutions who are traveling in Sawahlunto City. 3) As well as general visitors from inside and outside the area who are interested in the history of Sawahlunto City.

In general visitors from high school students in Sawahlunto City will visit the Museum individually rather than groups from the school. This is because it is close to the school and their place of residence and the age that is considered to be an adult to come to visit the museum independently. Whereas students from Kindergarten to Middle School will come in groups and be accompanied by their teacher.

The museum itself has facilitated museum services such as providing an Audio Visual room to convey information about the history of the Museum and the history of mining in the City of Sawahlunto. Through this short video screening, visitors will get information and general description about the history of Sawahlunto City when it was controlled by the Dutch. After the video screening, visitors will be accompanied by museum officials to look around the collection of objects and photographs of historical relics related to the history of Sawahlunto City. As in the Gudang Ransum Museum, visitors will be taken to a room where the Dutch overseers prepare cooking utensils to prepare food for miners in the past.

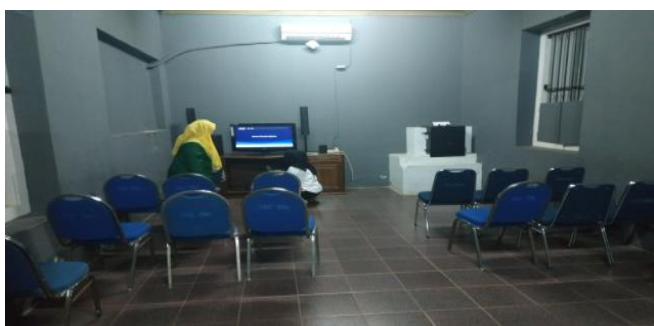

Picture 1. Audiovisual Room 
While at the Kereta Api Museum visitors after watching a short video will be taken to see objects related to the train such as carriages (one of the historic ones is the train named Mak Itam), rails, railroad regulators, clock bells used at the train station etc.

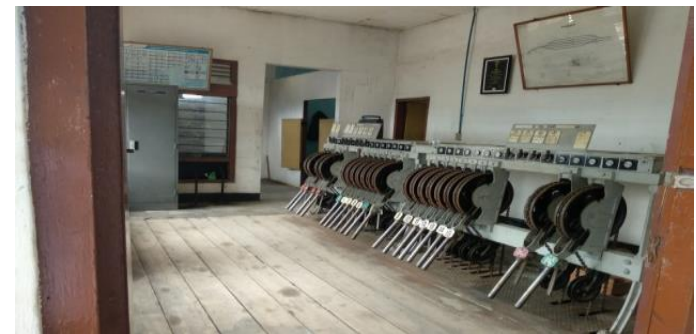

Picture 2. One of the Kereta Api museum's collections

Museum employees who accompany visitors will explain one by one the collections in the Museum based on their function in the past and the history of the existence of these objects. Through this assistance, visitors are expected to be able to understand history and be able to freely ask the accompanying officers. The museum is also active in promoting its existence by holding various kinds of races which are designated from kindergarten to high school students. Through this activity the Museum expects the public to know the Museum and be interested in visiting the Museum.

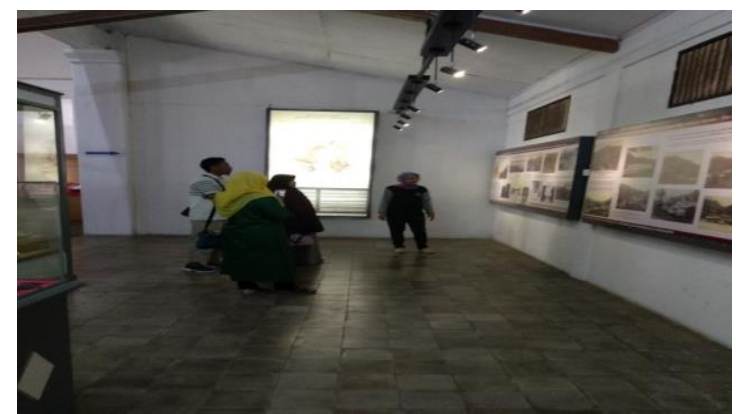

Picture 3. Explanation of the museum manager to visitors

\section{CONCLUSION}

Seeing the importance of museums as a medium of learning history in schools, history teachers should start using the museum as a medium of learning. For this reason, it is necessary to provide prior understanding because there are still many history teachers who do not understand the learning model using this museum. It is hoped that with this research, it can be seen the problem of the lack of use of museums as a medium in learning history and the solution of these problems.

\section{REFERENCES}

[1] Asyhar, Rayandra, Kreatif Mengembangkan Media Pembelajaran. Jakarta: Gaung Persada. 2011.

[2] Ahmad, Tsabit Azinar,Strategi Pemanfaatan Museum Sebagai Media Pembelajaran Pada
Materi Zaman Prasejarah. Jurnal Paramita.Volume 20 No. 1. 2010.Garragan, S.J, Gilbert. J., A Giude to Historical Method, New York:Fordham University Press.

[3] Hartati, Ummi, Museum Lampung Sebagai Media Pembelajaran Sejarah Jurnal Historia Volume 4, Nomor 1, Tahun 2016, ISSN 2337-4713.

[4] Latif, Abdul, Pendidikan Berbasis Nilai Kemasyarakatan.Bandung: Reflika Aditama. 2007.

[5] Kartodirdjo, Sartono,Pendekatan Ilmu Sosial Dalam Metodologi Sejarah, Jakarta: Gramedia.1992.

[6] Kumar, Singh Prabhas, Museum And Education. Journal OHRJ.Volume XIVII.No.1. Tanpa Tahun.

[7] Mahnun,Nunu, MediaPembelajaran (Kajian terhadap Langkah-langkah Pemilihan Media dan Implementasinya dalam Pembelajaran). Jurnal Pemikiran Islam; Vol. 37, No. 1.2012. 